\title{
Allium formosum Sennikov \& Lazkov (Amaryllidaceae), a new species from Kyrgyzstan
}

\author{
Alexander N. Sennikov', Georgy A. Lazkov² \\ I Botanical Museum, Finnish Museum of Natural History, P.O. Box 7, 00014 University of Helsinki, Finland; \\ \& Herbarium, Komarov Botanical Institute of Russian Academy of Sciences, Prof. Popov str. 2, 197376 St. \\ Petersburg, Russia 2 Laboratory of Flora, Institute of Biology and Soil Science, Kyrgyz Academy of Sciences, \\ 720071 Bishkek, Kyrgyzstan
}

Corresponding author: Alexander N. Sennikov (alexander.sennikov@helsinki.fi)

Academic editor: L. Peruzzi | Received 16 November 2012 | Accepted 8 March 2013 | Published 2 April 2013

Citation: Sennikov AN, Lazkov GA (2013) Allium formosum Sennikov \& Lazkov (Amaryllidaceae), a new species from Kyrgyzstan. PhytoKeys 21: 29-36. doi: 10.3897/phytokeys.21.4130

\begin{abstract}
Allium formosum Sennikov \& Lazkov sp. nov. is described as new to science and illustrated. This species is the second member of $A$. sect. Spathulata F.O.Khass. \& R.M.Fritsch, being different from A. spathulatum F.O.Khass. \& R.M.Fritsch in larger, broader, obtuse and more intensely purple-coloured tepals, and in a more robust habit. It is a local endemic of Babash-Ata Mt. Range situated east of Fergana Valley in Kyrgyzstan, recommended for legal protection as Endangered because of the very small population size in its only locality.
\end{abstract}

\section{Keywords}

Central Asia, conservation, endemism, hotspot, new species, plant protection, Western Tian-Shan

\section{Introduction}

The genus Allium L. is highly speciose in the former Soviet part of Central Asia. The latest synopsis (Khassanov 2008) lists nearly 250 species and subspecies, and this number is constantly growing with descriptions of new species from nearly all mountainous areas of this region.

Kyrgyzstan is a Central Asian country with a rich native flora, assessed at nearly 3800 native species of vascular plants (Lazkov and Sultanova 2011) and still remaining seriously underexplored (Kamelin 2002). The old Flora of Kirghiz SSR (Nikitina and Kaschenko 1951) listed 67 species of Allium; this number has been significantly increased with a further exploration of the country by local botanists and Allium taxono- 
mists. The current inventory is being performed after publication of the new checklist of vascular plants of Kyrgyzstan (Lazkov and Sultanova 2011) that counted 85 species of Allium, making an increase of $25 \%$ for the last 60 years.

During the years 2009-2011 botanists of the Botanical Museum of the University of Helsinki, in collaboration with the Institute of Biology and Soil Science of the Kyrgyz Academy of Sciences, made expeditions to collect plants in Kyrgyzstan. The expeditions focused on the most difficult and diverse taxonomic groups, with emphasis on local endemics. Several taxonomic novelties and new records resulted from these travels (Sennikov 2010, 2011; Sennikov et al. 2011). One of the new species belongs to Allium sect. Spathulata F.O.Khass. \& R.M.Fritsch, and its description is presented here.

Allium sect. Spathulata was established (Khassanov 2000) for the single species A. spathulatum F.O.Khass. \& R.M.Fritsch that was discovered only recently (Fritsch et al. 1998). This miniature plant has a very limited local occurrence and remained undetected in spite of its location within the limits of the famous Sary-Chelek Nature Reserve (Kyrgyzstan), where its type locality is situated nearby the headquarters of the Nature Reserve. These plants are so rare and minute that they were unnoticed for 100 years of botanical studies in the Nature Reserve.

When originally described, $A$. spathulatum was considered unique in $A$. subgen. Allium because of the presence of spathules and papyraceous tunics, ovoid bulbs, and the absence of bulblets (Khassanov 2000). Although this species was not included in the molecular phylogeny of Allium (Friesen et al. 2006) yet, which still embraces selected sections only, it was speculated to be less specialised in the subgenus from the primitive state of its several characters, e.g. an inflorescence with numerous long bracteoles ("spathules"), papery-like bulb tunics, and a symmetric karyotype with small satellites (Fritsch et al. 1998; Friesen et al. 2006).

\section{Materials and methods}

A description of the new taxon and its relative is based on herbarium vouchers and field observations, following the standard used in the taxonomy of Allium. One population per species is used. Measures are taken from dried plants.

Distribution maps are compiled using R software environment for statistical computing and graphics (R Development Core Team 2008). The base maps are taken from the Digital Chart of the World, Arc/INFO resource provided by the Environmental Systems Research Institute, Inc., the Pennsylvania State University Libraries.

\section{Data resources}

Specimen information is deposited in the database of records in vascular plants of Kyrgyzstan (Sennikov and Lazkov 2012) that is published also through the Global Biodiversity Information Facility (GBIF) and in the Dryad Data Repository at doi: 10.5061/dryad.pq $87 \mathrm{t}$ 


\section{Taxonomic treatment}

Allium formosum Sennikov \& Lazkov, sp. nov. (Allium sect. Spathulata F.O.Khass. \& R.M.Fritsch)

urn:lsid:ipni.org:names:77126319-1

http://species-id.net/wiki/Allium_formosum

Fig. 1

Ab Allio spathulato statura majore (caulibus ad $30 \mathrm{~cm}$, nec ad $20 \mathrm{~cm}$ altis), spathulis brevioribus paucioribus, floribus pluris (ad 30, nec ad 20), tepalis obscuriore roseolo-purpureis, longioribus (6-7.5 mm, nec 4-5.5 mm longis) latioribusque (2-2.5 mm, nec $2 \mathrm{~mm}$ latis), apice obtusioribus (nec acutis) basi subrotundis (nec distincte angustatis) differt.

Type. Kyrgyzstan. Babash-Ata Range: Kara-Köl River valley, left riverside, alt. 1650 m, $41.53^{\circ} \mathrm{N}, 72.68^{\circ} \mathrm{E}, 14.07 .2010$, A. Sennikov \& G. Lazkov 132 (H 1750496, holotype; isotypes FRU, H 1750497).

Description. Bulbs subglobose, $7-8 \mathrm{~mm}$ in diameter, ca. $8 \mathrm{~mm}$ long, inner tunices slightly violaceous, very thin, transparent, papyraceous, with several longitudinal nerves, outer ones light-grey, decomposing. Bulblets missing. Scape single, 20-25 (30) cm long, up to $1.5 \mathrm{~mm}$ in diameter, solid, dark green with a slight purple tint at the base. Leaves 2(3), linear, not exceeding the stems, upright, with the blade up to $20 \mathrm{~cm}$ long, ca. 1.5 $\mathrm{mm}$ wide, round-appressed and fistulose in the section, dark green, glabrous, with sheaths up to $10 \mathrm{~cm}$ long. Spathe membranous, completely divided into two elongate valves 4-6 $\mathrm{mm}$ long, reflexed. Inflorescence hemisphaerical, rather lax, with 7-30 developed flowers and ca. 5 abortive buds; pedicels thin, basally thickened, straight, dark-green, of the same length, ca. $1.5 \mathrm{~cm}$ long, some of them being embraced in narrow spathules ca. 1 $\mathrm{mm}$ long. Perianth cupuliform, intensively pinkish-purpureous in the upper two thirds, basally whitish, with dark-purpureous median veins. Tepals $6-7.5 \mathrm{~mm}$ long, 2-2.5 mm wide, oblong, obtuse at the apex, subrotund and only very slightly narrowed to the base. Filaments shorter than tepals, $2.5-3 \mathrm{~mm}$ long, white, connected and fused with sepals at the base, outer ones with the triangular base, inner ones broader, tricuspidate. Anthers ca. $0.4 \mathrm{~mm}$ long, yellow. Ovary ca. $2 \mathrm{~mm}$ long, $2-2.5 \mathrm{~mm}$ in diameter, subglobular. Style slightly over $1 \mathrm{~mm}$ long, white. Capsule and seeds not known.

Phenology. Flowering in July, fruiting unknown.

Ecology. The species occurs in the low-altitude forest zone (altitudes of ca. 1600$1700 \mathrm{~m}$ ) in river valleys, on open sunny slopes with sparse savannoid vegetation, sheltered by stones. The plants grow clustered in small patches, suggesting the most successful establishment nearby mature plants (vegetative reproduction is not known in this section).

Distribution. Possibly a narrow endemic of Babash-Ata Mt. Range, Kyrgyzstan (Fig. 3), so far known from the type locality only.

Proposed conservation status. The distribution area of this species is like those of other local endemics of the mountains east of Fergana Valley. A single locality is known, where ca. 10 clusters of flowering plants were noticed. Even though no imme- 


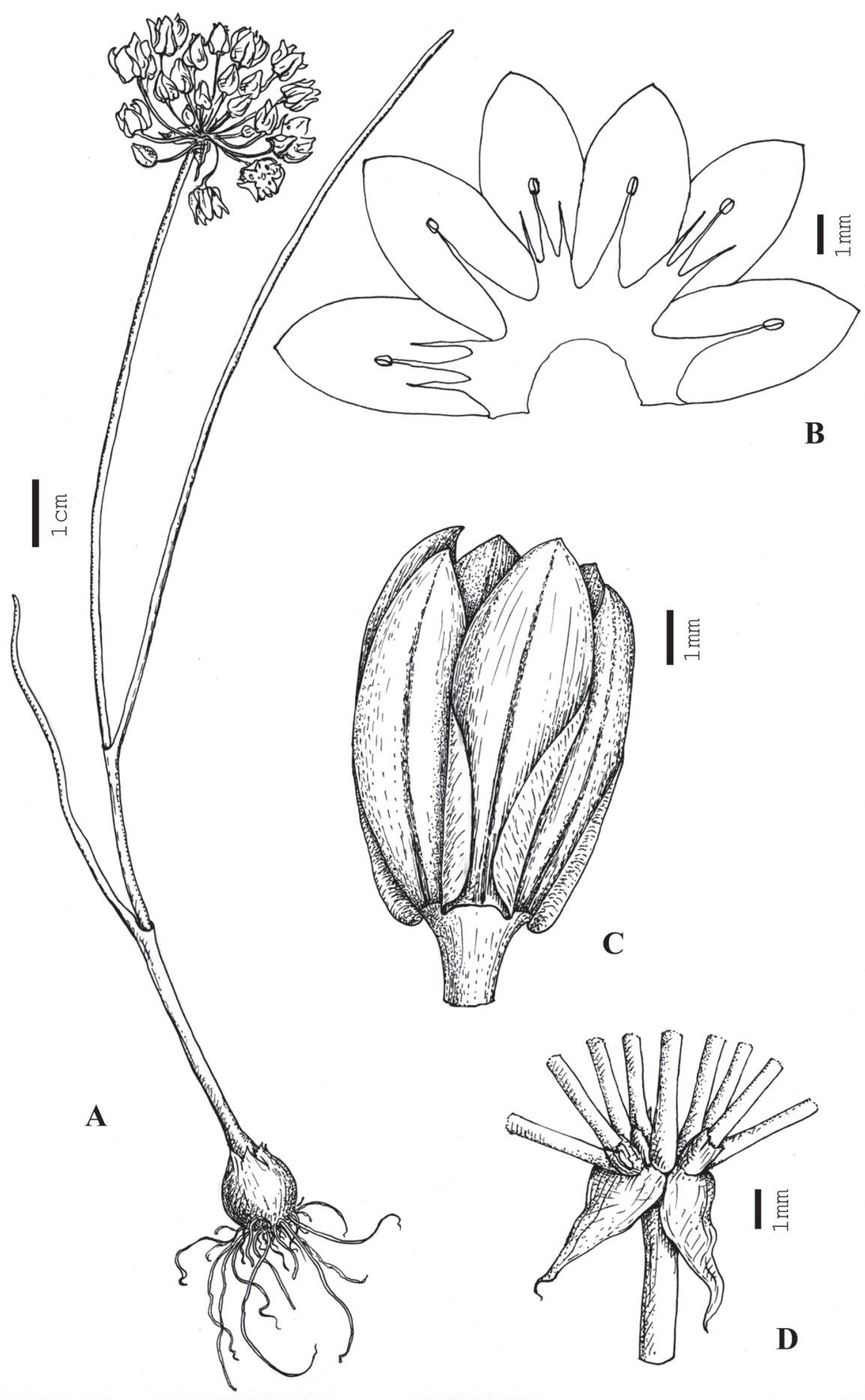

Figure I. Allium formosum. A habit. B inner side of the perianth with stamina. C flower. D basal part of the umbella. Drawn from the type (H 1750496). 
diate threat was observed, the area is in active use, first of all for grazing and mining. For this reason and because of the very limited distribution area and a small size of the only population known to date (criterium D: population size estimated to number fewer than 250 mature individuals), this taxon may be recommended for protection as Endangered (IUCN 2001).

Etymology. The new species is named because of its elegant habit and beautiful colouration of the perianth, transitional between deeply pink and purple; Lat. formosum = beautiful.

\section{Discussion}

Allium spathulatum F.O.Khass. \& R.M.Fritsch has been recently described from Chatkal Range, Sary-Chelek Nature Reserve, vicinities of Arkyt village (Fritsch et al. 1998). This species was recollected on 10.06 .2010 by G. Lazkov from the slopes on the left side of Kojo-Ata River valley, situated immediately outside the entrance to Sary-Chelek Nature Reserve, in ca. $1 \mathrm{~km}$ from the original locality. The plants collected at that site (FRU, H 1750495, 1750506) were in a complete agreement with the protologue.

The plants from Babash-Ata Mts., Kara-Köl River differ from A. spathulatum mostly in having longer and broader tepals, which are obtuse at the apex and less narrowed to the base (Fig. 2), and in a larger size of the whole plant. The flowers seem to be more numerous. Some pedicels are embraced by spathules which are generally less developed (shorter and less numerous) than in A. spathulatum. These differences warrant the segregation of these plants into a separate taxon; the rank of species is preferred here because the differences are complex and constant. Another example of a similar distinction in the floral characters is the Central Asian pair $A$. tianschanicum Rupr. $-A$. kokanicum Regel, where major differences are also in the size and shape of tepals.

Another difference is observed in the shape of flowers which open less widely and thus look cupuliform in A. formosum (campanulate in A. spathulatum). However, this difference may appear dependent on weather conditions and needs to be proven by further observations.

The distance between the localities of $A$. spathulatum and A. formosum, both narrow endemics of mountains surrounding the eastern end of Fergana valley, is about 60 $\mathrm{km}$ (Fig. 3). The area of the eastern part of Chatkal Range and the northern outliers of Fergana Range (Babash-Ata and neighbouring mountains) is well known for the concentration of many narrow endemics, being a hotspot of plant diversity in Western Tian-Shan (Lazkov et al. 2002). The territories surrounding the eastern end of Fergana valley harbour many narrow endemics of Allium as well (see a brief review in Fritsch et al. 1998), and our discovery stresses the need of further explorations and plant protection in this area. Because of vulnerability of the species, we anticipate its inclusion in the forthcoming Red Data Book of Central Asia and the next edition of the Red Data Book of Kyrgyzstan. 

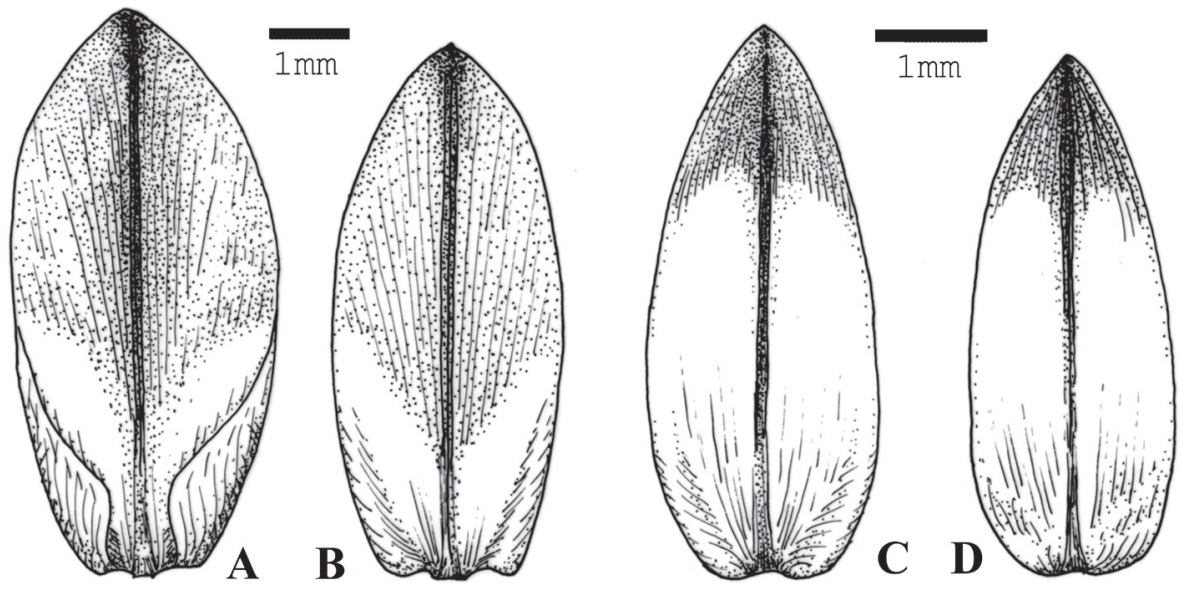

Figure 2. Allium formosum. A outer tepal B inner tepal. Drawn from the type (H 1750496). Allium spathulatum C outer tepal D inner tepal. Drawn from Lazkov s.n. (H 1750506).

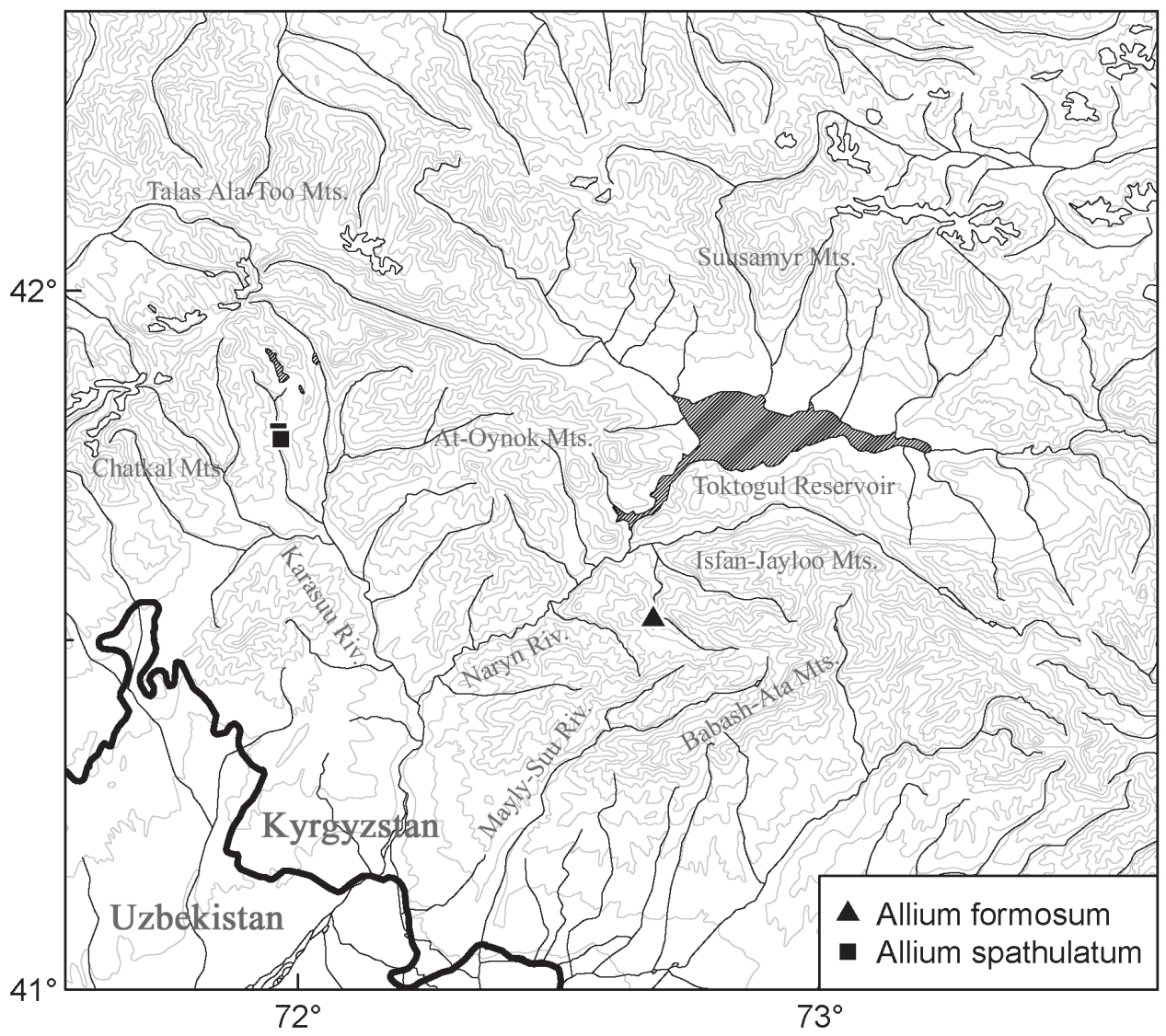

Figure 3. Distribution areas of Allium formosum and Allium spathulatum. 
The present state of the Allium research in Central Asia, especially descriptions of new species that are still regularly published, clearly show that the species inventory in this speciose and difficult genus is far from complete. In the absence of elaborated molecular phylogenies we feel premature to speculate on the origin and age of our newly discovered species.

\section{The members of $A$. sect. Spathulata may be keyed out as follows}

1 Plants up to $20 \mathrm{~cm}$ tall. Tepals narrowly oblong, $4-5.5 \mathrm{~mm}$ long, $2 \mathrm{~mm}$ wide, acute at the apex and narrowed to the base, pinkish in the upper third .........

A. spathulatum

- $\quad$ Plants up to $30 \mathrm{~cm}$ tall. Tepals oblong, 6-7.5 mm long, 2-2.5 mm wide, obtuse at the apex, subrotund and very slightly narrowed to the base, intensely pinkish-purpureous in the upper two thirds

A. formosum

\section{Other specimens examined}

Allium spathulatum F.O.Khass. \& R.M.Fritsch

Kyrgyzstan. Chatkal Range (S side): immediately $S$ of Sary-Chelek Nature Reserve, left side of Kojo-Ata River valley, on rocks, $41.7^{\circ} \mathrm{N}, 71.9^{\circ} \mathrm{E}, 10.06 .2010$, G. Lazkov (FRU, H 1750495, 1750506).

\section{Acknowledgements}

We are grateful to Sampsa Lommi (Helsinki) for the distribution map. Nijole Kalinauskaite (Helsinki) performed the drawing of the plant habit and Mikhail Kozhin (Moscow) has skilfully drawn the tepals. The field trip to Kyrgyzstan in 2010 was supported by Millennium Seed Bank (to G.L.) and Botanical Museum of the University of Helsinki (to A.S.). The text benefited from critical comments of two anonymous reviewers and the editors.

\section{References}

Friesen N, Fritsch RM, Blattner FR (2006) Phylogeny and new intrageneric classification of Allium (Alliaceae) based on nuclear ribosomal DNA ITS sequences. Aliso 22: 372-395.

Fritsch RM, Khassanov FO, Friesen NW (1998) New taxa, new combinations, and taxonomic remarks on Allium L. from Fergan depression, Middle Asia. Linzer Biologische Beiträge 30: 281-292. 
IUCN Species Survival Commission (2001) IUCN Red List Categories: Version 3.1. IUCN, Gland and Cambridge.

Kamelin RV (2002) Brief survey of the vegetation of Kirghizia. Phytogeographical regions of Kirghizia. In: Pimenov MG, Kluykov EV, The Umbelliferae of Kirghizia. KMK Scientific Press, Moscow, 3-18.

Khassanov FO (2000) Subinfrageneric grouping in genus Allium subgenus Allium. In: Ashurmetov O, Khassanov F, Salieva Y (Eds) Plant life in South-West and Central Asia (5th International symposium, Tashkent '98). Chinor ENK, Tashkent, 107-112.

Khassanov FO (2008) The genus Allium L. in the flora of Central Asia. Abstract of Thesis for the Degree of Dr. Sci. in Biology. Scientific-Applied Research Centre "Botany", Uzbek Academy of Sciences, Tashkent.

Lazkov GA, Sultanova BA (2011) Checklist of vascular plants of Kyrgyzstan. Norrlinia 24: 1-166.

Lazkov GA, Sultanova BA, Kenjebaeva NV (2002) The level of studies on the flora of the Western Tian-Shan within Kyrgyzstan and the centres of its local endemism. In: Shukurov EJ (Ed.) Biodiversity of Western Tian-Shan: Achievements and prospects. Proceedings of the scientific conference, Bishkek, 26 Dec 2001. Central Asia Transboundary Biodiversity Project, Bishkek, 172-175.

Nikitina EV, Kaschenko LI (1951) Allium L. In: Vvedensky AI (Ed.), Flora of Kirghiz SSR. Academy of Sciences of the Kirghiz SSR, Frunze, 3: 50-96.

R Development Core Team (2008) R: A language and environment for statistical computing. R Foundation for Statistical Computing, Vienna.

Sennikov AN (2010) A revision of Cousinia sections Alpinae (syn. Carduncellus), Subappendiculatae and Tianschanicae (Asteraceae) in the Kirghizian Tian-Shan and the neighbouring territories. Phytotaxa 5: 1-30.

Sennikov AN (2011) Cousinia hystricocephala (section Tianschanicae, Asteraceae), a new species from Central Asia. Phytotaxa 25: 23-30.

Sennikov AN, Lazkov GA (2012-, continuously updated) Distribution records in vascular plants of Kyrgyzstan (according to herbarium specimens kept at the Botanical Museum, University of Helsinki). http://archive.org/details/DistributionRecordsOfVascularPlantsInKyrgyzstan (accessed 13.11.2012)

Sennikov AN, Lazkov GA, Uotila P, Weber H (2011) Taxonomic corrections and new records in vascular plants of Kyrgyzstan. Memoranda Societatis pro Fauna et Flora Fennica 87: 41-64. 